\title{
一带一路背景下天津跨境电商发展现状及建议
}

赵建辉

天津职业大学

DOI:10.32629/mef.v3i3.768

[摘 要] 本文从2001年中国加入世界贸易组织, 2013年习近平主席发起一带一路倡议至今, 分析中国跨境电商发展以及天津 的发展状况, 就如何挖掘一带一路的商机, 以及天津的跨境电商发展如何融入京津冀一体化发展战略, 提出了天津跨境电商 产业发展的建议。

[关键词]一带一路; 跨境电商; 京津冀一体化

Tianjin Cross-border E-commerce Development Status and Suggestions under the Background of the One Belt and One Road

Jianhui Zhao

Tianjin Vocational Institute

[Abstract] This article has analyzed China's cross-border e-commerce development and Tianjin's development status since China joined the World Trade Organization in 2001 and President Xi Jinping initiated the One Belt and One Road in 2013, on how to tap the business opportunities of the One Belt and One Road and how Tianjin's cross-border $\mathrm{e}^{-}$-commerce development is integrated into the Beijing-Tianjin-Hebei integrated development strategy, suggestions are put forward for the development of Tianjin's cross-border e-commerce.

[Keywords] One Belt and One Road; cross-border e-commerce; Beijing-Tianjin-Hebei integration

\section{1 “一带一路” 背景下中国的跨境电商现状}

2001年12月11日中国加入世界贸易组织, 自2001年至 今, 中国进出口贸易额提升是新中国成立以来最快的, 相比 其他国家增速也是最高的。根据世界贸易组织 (WTO) 公布的 2017年全球贸易总额排行榜显示, 中国大陆进出口贸易总额 为 4.1052 万亿, 占全球贸易比重的 $11.48 \%$, 排名全球第一。 根据国际贸易生产要素禀赋论和比较优势论, 由于各国资源 禀赋和价格不同，各国之间相互协作对各国的发展更有利, 中国正式抓住了这一波世界产业的分工优势, 迅速崛起。 2008年从美国发生的经济危机席卷了全球, 使各国的经济增 长陷入了低谷, 世界各国的贸易额虽然有所波动, 但是一直 是逐步增长的。虽然贸易保护主义近些年来逐渐抬头, 但是 国际间的分工合作一直是主流, 为了开拓新市场, 推动各国 的共同发展，2013年中国国家主席习近平提出共同建设 “丝 绸之路经济带” 和 “ 21 世纪海上丝绸之路” 简称 “一带一路” 倡议。

2014年第一届世界互联网大会在浙江乌镇成功召开, 中 国进入了 “互联网+” 的新时代, 同时跨境电商行业的发展 成为了资本追逐中的新热点。2015年3月28日，国家正式发 布《推动共建丝绸之路经济带和 21 世纪海上丝绸之路的愿景 与行动》。“一带一路” 战略正式进入了推进落实阶段。“一 带一路”与 “互联网十” 的完美结合, 为中国跨境电商提供 了快速发展的宏观环境。截止2018年3月, “一带一路” 战略 已经有 71 个国家和地区加入, 各国和地区的总人口规模超过
34.4 亿, 人口规模占到世界人口的 $47.6 \%$, 经济总量预测达 到了 14.5 万亿美元, 国际贸易总额为 9.3 万亿美元。“一带一 路” 战略已成为推动经济全球化发展不可或缺的力量。自从 2013年一带一路倡议发起以来, 中国的GDP从590422亿增长 到2017年的827122亿, 国民收入的增长增加了对进口商品的 需求。电子商务研究中心发布的《2018年（上）中国跨境电 商市场数据监测报告》显示: 2018 上半年中国进口跨境电商 交易规模达 1.03 万亿元, 同比增长 $19.4 \%$, 预计 2018 全年将 达到 1.9 万亿元。《中国进口消费市场研究报告》显示, 随着 跨境电商平台崛起, 中国跨境电商零售进口渗透率已经从 2014 年的 $1.6 \%$ 迅速增加到 2017 年的 $10.2 \%$ 。

\section{2 天津跨境电商发展现状}

自从中华人民共和国建国以来, 天津市一直作为北方大 港口城市, 依托其独特的地理位置优势, 通过发展对外贸易, 建国之后一度成为了中国北方的经济中心。自1994年以来天 津市着力发展外向型经济, 天津滨海新区纳入国家总体发展 规划。2014年12月12日, 位于天津市滨海新区的中国 (天津) 自由贸易试验区正式获得国家批准设立。2015年4月21日, 中国（天津）自由贸易试验区正式挂牌。中国（天津）自由 贸易试验区为中国北方第一个自贸区。天津保税区积极探索 新的贸易方式, 经验和模式, 深化改革。以跨境电子商务, 汽车平行进口和文化服务贸易为代表的新兴贸易形式的贸 易模式得到了发展, 成为自由贸易区对外贸易的新增长点。 2016年1月, 天津作为第二批全国跨境电商试点城市, 获准 
建设跨境电商综合试验区, 很多传统的贸易企业以及消费者 开始通过跨境电商交易模式与其他国家的企业和消费者进 行交易。目前天猫国际等跨境电商领军企业均已入住天津, 并在海外的北美和欧洲等主要跨境电商市场设立了海外仓 库; 已有一万多家传统外贸企业应用电子商务, Ebay、亚马 逊和谷歌等一批国外的跨境电商企业与天津市建立了合作, 谷歌体验中心落户航空商务区, 利用互联网大数据助力天津 跨境电商发展; 天津港保税区、东疆保税港等成为首批跨境 电子商务创新实验区。2018年，天津港保税区交易额达 15 亿元人民币，交易单数超过 1100 万单。较 2017 年的 462.84 万单数和进口额 11.92 亿元分别增长 2.38 倍和 $25.84 \%$ 。

天津市目前也正在推进东疆保税港区、天津港保税区、 航空商务区、武清区等四个跨境电子商务创新试验区建设。 天津港作为全球供应链的重要节点, 在跨境电子商务供应链 一体化方面具有供应链整合优势, 通过整合现有资源, 构建 新型贸易模式, 对于天津港创新商业模式具有重要意义。

表 1 天津港从跨境电商平台至今的重要事件

\begin{tabular}{|c|c|}
\hline 时间 & 事件 \\
\hline 2016 年 3 月 & 天津市地方版跨境电子商务信息系统上线试运行 \\
\hline 2016 年 6 月 & 率先全面切换海关总署跨境电子商务进口统一版信息化系统 \\
\hline 2016 年 11 月 & “双 11 ” 当天统一版接受清单申报值达 4 万余票, 占据总署统一版接受申报量近 9 成 \\
\hline 2016 年 6 月 & 电商大促期间, 业务量达去年 “双 11 ” 期间单量的 3.14 倍 \\
\hline 2017 年 11 月 & “双 11 ”电商大促期间, 业务量同比增加 5.22 倍, 当天业务量同比增长 4.48 倍 \\
\hline 2017 年 12 月 & 跨境电商保税进口申报入区货值 11.92 亿元 \\
\hline 2018 年 11 月 & 双十一活动当天通关单数 119.7 万, 与上年相比增长了 4.35 倍 \\
\hline 2018 年 12 月 & 全年接受清单申报 1100 万单, 同比增长 2.38 倍 \\
\hline
\end{tabular}

\section{3 天津跨境电商存在问题}

虽然天津的跨境电商发展速度是令人瞩目的, 但是该行 业发展目前仍存在着很多制约发展的阻碍。

\section{1 物流发展受限}

跨境电商的发展, 必须依靠物流产业的推动。跨境电商 的商品物流需要经过国内物流, 国内报关, 物流运输, 国外 报关和国外物流等五个环节才能最终到达国外消费者。天津 目前物流行业信息化程度不高, 虽然近些年来天津已经陆续 建成了一些智能仓储物流系统, 但是和欧美相比还有很大差 距, 在国内也落后于南方省份。近几年以来物流成本在不断 攀升, 而跨境贸易的利润一直比较微薄, 抑制了中国跨境电 商行业的快速发展。2018年的10月, 美国启动退出万国邮政 联盟的程序。该行动直接回导致发达国家向发展中国家的补 贴损失, 这会造成在电商平台上价格为 5 美元以下的跨境直 邮产品, 由于美国邮局邮费的增长, 物流成本的上升, 可能 直接出局。

\section{2 开发 “一带一路” 国家资源不足}

据《一带一路贸易合作大数据报告2018》报道, 天津进 出口总额在全国排名中只排在第九位。天津的进出口贸易总 额从2013年的7960亿到2017年的7646. 85亿元, 贸易额不升
反降, 与天津的北方大港地位很不相符。

3.3 天津市工资水平相对较低, 吸引人才能力较弱

2013年末全市常住人口 1472.21 万人，其中，外来人口 440.91 万人。截至 2017 年年末, 全市常住人口 1556.87 万人, 比上年末减少 5.25 万人; 其中，外来人口 498.23 万人，占全 市常住人口的 $32.0 \%$ 。相比 2013 年, 全市常住人口仅增加了 84.63 万, 外来人口也仅增加 57.32 万。与之相邻的北京市人 口 2013 年常住人口 2114.8 万, 外来人口 802.7 万, 截止 2017 年 2170.7 万, 外来人口 794.3 万, 虽然北京市人口呈下降趋 势, 是因为北京市的城市负荷严重, 需要疏解人口。与之相 比天津市从未实行过疏解人口, 并且在 2015 就开始实施人才 绿卡，却无法吸引足够的人才。

2013年天津全年城市居民人均可支配收入 32658 元。 2017 年全年全市居民人均可支配收入 37022 元。4年时间工资 水平仅增长 $13.3 \%$ 。2013年北京市人均可支配收入为 40321 元, 截止 2017 年末, 北京市人均可支配收入增长到 57230 元。 无论是从绝对值还是相对值, 北京的工资水平要比天津高很 多。虽然天津市在2015年开始的人才绿卡在福利待遇上非常 优厚, 也吸引了一些领军人物如院士科研带头人等, 却无法 吸引到足够的基层人才, 而基层人才才是跨境电商最需要的 人才储备。

据《2017年跨境电商行业人才管理调研分析报告》显示, 未来三年中国跨境电商相关领域的人才缺口将高达 450 万, 2018年, 这一缺口正以 $30 \%$ 以上的增长率在扩大。天津市目 前有高等院校55所, 截止目前开展跨境电商教学的本科高校 有天津财经大学、天津商业大学、天津城建大学、天津职业 技术师范大学和天津商业大学宝德学院; 另外还有天津职业 大学、天津商务职业学院、天津交通职业学院和天津国土资 源和房屋职业学院4所高职院校。高等院校专业开设不足, 短时间内无法培养出满足行业快速发展所需人才。

\section{4 天津跨境电商发展建议}

4.1 根据2010年国务院印发《全国主体功能区规划》以 及国务院批复的《天津市城市总体规划 (2005年-2020年)》, 未来天津是的定位是: 中国北方经济中心、环渤海地区经济 中心、中国北方国际航运中心、中国北方国际物流中心、国 际港口城市和生态城市。其中北方国际航运中心和北方国际 物流中心和物流行业紧密相关。针对目前天津物流发展瓶 颈，政府应该加大扶持力度，认真执行《天津市物流业空间 布局规划（2017-2035年)》，从政策上支持物流行业发展， 对外招商引资, 实现与国际接轨的物流运输中心建设, 提升 物流行业信息化自动化智能化发展, 推动物流资源整合, 促 进物流产业转型升级和优化发展, 提升天津市物流服务辐射 能力, 积极对接雄安新区规划, 实现京津冀联动物流行业无 缝接轨。

4. 2 积极实行走出去战略, 积极主动对接一带一路参与 国。一带一路沿线有很多国家尚未开发, 这也意味着有很多 机会。天津应向广东、江苏、浙江、山东和上海学习, 积极 


\section{大数据专业实验教学创新模式研究}

\section{张雯莉}

桂林旅游学院

DOI:10.32629/mef.v3i3.735

[摘 要] 信息技术推动了大数据产业的发展，而大数据技术有效的提高了我国的信息共享和传递的速度。现在我国大数据 还处于起步发展阶段, 大数据资源存在的问题主要体现在数据兄余和数据质量等方面, 从而导致了大数据相关的岗位十分紧 缺。结合大数据专业背景, 本文就课程体系设置、实验内容以及教学模式等方面进行了分析, 并提出了教学模式的创新研究。 [关键词] 大数据专业; 实验教学; 教学模式

\section{Research on Innovation Model of Experimental Teaching for Big Data Major Wenli Zhang \\ Guilin Tourism University}

[Abstract] Information technology promotes the development of big data industry, and big data technology effectively improves the speed of information sharing and transmission in our country. China's big data is still in the initial development stage, the problems of big data resources are mainly reflected in data redundancy and data quality, which leads to the shortage of big data-related jobs. Combined with the big data professional background, this article analyzes the curriculum system, experimental content and teaching mode, and puts forward innovative research on the teaching mode.

[Keywords] big data major; experimental teaching; teaching mode

随着信息技术的飞速发展，信息的生产与传输效率达到 了前所未有的便捷, 导致了数据资源呈现出爆发增长的趋 势。这一情况知识传统的信息处理方式不再适合当前海量的 数据。因此, 大数据技术成为了当前广泛关注的一种新兴技 术。随着大数据技术的创新和应用力度不断加大, 社会上对 于大数据人才的需求也愈发广泛, 但是大数据专业的教学模 式、课程设置、实验条件等方面比较缺乏, 如何创新、改革 大数据专业实验教学模式已经成为当前高校的探讨热点。

\section{1 大数据专业实验教学现状}

开拓新领域。利用天津的港口天然优势, 把跨境电商做到一 带一路沿线国际城市, 利用地缘优势, 连接辐射东北亚的蒙 古国和俄罗斯、中亚五国、乌克兰、白俄罗斯、日本、韩国 和新加坡，并积极开发新的国家资源。

利用天津夏季达沃斯论坛的机会, 积极和国外建立紧密 的贸易关系, 积极推动一带一路沿线国家投资合作和贸易往 来。通过跨境电商行业把产品和技术推向沿线国家, 加大合 作力度, 实现天津跨境电商行业的飞跃发展。

4. 3 吸引人才, 提升工资待遇。继续推进天津市的海河 人才计划, 吸引外来人才落户天津, 为天津的行业发展引进 人才; 天津的高等院校积极创造条件, 培育本土人才, 弥补 人才缺口, 并能留住人才; 积极培训在岗人员, 提高现有跨 境电商从业人员水平。积极提升天津市的工资待遇, 通过政 府政策扶持, 资金投入和就业环境提升, 打造一个引进人才,

\section{1 大数据专业配套基础设施贯乏}

因为社会上对于大数据专业人才的需求在不断上升, 许 多高校都增设了大数据专业, 甚至增加了大数据专业学院。 但是, 因为我国的大数据专业教学还处于起步发展阶段, 所 以在教学过程中明显可以发现缺乏配套基础设施的问题, 这 一情况对大数据专业实验教学造成影响。大数据专业教学是 以海量数据资源为基础, 并且由于数据资源的来源非常复 杂, 学生无法独立收集大数据基础数据资源。而当前已经有 部分高校为大数据专业构建了专业的实验室, 但是在教学过

培养人才, 提供就业和人才定居联动的良性循环, 推动天津 市跨境电商的快速发展。

\section{[参考文献]}

[1] 郭晓莹. 北方网2017年天津跨境电商共计进口额超 过11亿元[EB/OL].(2018-04-23)http://news.enorth.com.cn/ system/2018/04/23/035398806.shtm1.

[2] 搜狐网. 天津跨境电商发展时间表 [EB/OL]. (2018-02-07)http://WwW.sohu.com/a/221458370_99924358.

[3]谭钧元, 梁爽.天津市跨境电子商务发展问题及对策 分析[J].现代商贸工业,2018(4):49-50.

\section{作者简介：}

赵建辉（1983--), 男, 汉族, 河北石家庄人, 助教, 硕士, 研究方向: 国际商务、跨境电商。 